\title{
PENGARUH PEMBELAJARAN KONTEKSTUAL DAN GAYA BELAJAR TERHADAP HASIL BELAJAR MEKANIKA TEKNIK SISWA KELAS $X$ PROGRAM KEAHLIAN TEKNIK GAMBAR BANGUNAN SMK NEGERI 1 LUBUK PAKAM
}

\author{
Muhammad Syafi' ${ }^{1)}$ Dr. Zulkifli Matondang, M.Si ${ }^{2)}$ \\ Pendidikan Teknik Bangunan, Fakultas Teknik Universitas Negeri Medan \\ Kementerian Riset Dan Teknologi, Fakultas Teknik Universitas Negeri Medan \\ e-mail : xavii.jr29.ms@gmail.com
}

\begin{abstract}
ABSTRAK
Penelitian ini bertujuan untuk mengetahui pengaruh model pembelajaran Kontekstual dan Gaya belajar terhadap hasil belajar Mekanika Teknik. Metode penelitian yang digunakan adalah quasi eksperimen semu. Pengambilan sampel penelitian secara acak, kelas Teknik Gambar Bangunan-A sebagai kelompok Eksperimen Kontekstual berjumlah 35 orang dan kelas Teknik Gambar Bangunan-B sebagai kelompok Eksperimen Konvensional berjumlah 35 orang. Variabel bebas dalam penelitian ini adalah : 1) Model Pembelajaran (Kontekstual) ; 2) Gaya Belajar; 3) Interaksi antara Model Pembelajaran dengan Gaya Belajar. Sedangkan variabel terikat adalah hasil belajar Mekanika Teknik. Data diambil melalui instrumen test berupa pilihan berganda berjumlah 23 soal, essai berjumlah 5 soal, dan instrumen nontest berupa angket motivasi belajar berjumlah 36 item. Berdasarkan pengujian hipotesis diperoleh : (1) Model Pembelajaran Kontekstual memberikan pengaruh yang lebih baik terhadap hasil belajar Mekanika Teknik dibandingkan Model Pembelajaran Konvensional dengan nilai uji hipotesis kompetensi sikap diperoleh thitung $=5,203>$ ttabel $5 \%=3,982$, kompetensi pengetahuan diperoleh thitung $=7,818>$ ttabel $5 \%=3,982$, dan kompetensi keterampilan diperoleh thitung $=4,218>$ tabel $5 \%=3,982$. (2) Gaya belajar siswa yang memiliki gaya belajar kinestetik memberikan pengaruh lebih tinggi terhadap hasil belajar Mekanika Teknik kompetensi pengetahuan dibandingkan dengan siswa yang memiliki gaya belajar visual dengan nilai uji hipotesis motivasi belajar diperoleh thitung $=12,368>$ ttabel $5 \%=3,982$. (3) Terdapat interaksi antara model pembelajaran dengan gaya belajar terhadap hasil belajar Mekanika Teknik kompetensi sikap diperoleh thitung $=4,602>$ ttabel 5\% $=3,982$.
\end{abstract}

Kata kunci: kontekstual, Gaya Belajar, Hasil Belajar.

\section{PENDAHULUAN}

Pendidikan

merupakan

suatu

pembekalan dan kualitas bagi setiap individu berupa pembentukan sikap, pengetahan dan keterampilan kerja yang secara langsung dan tidak langsung. Secara umum, pendidikan dipandang sebagai sesuatu yang penting untuk meningkatkan harkat dan martabat suatu bangsa dan untuk meningkatkan kemajuan suatu Negara yang lebih baik dari sebelumnya. Sesuai dengan tujuan pendidikan nasional yang dirumuskan dalam UUD No. 20 Tahun 2003 Pasal 3 yang menyatakan bahwa : Pendidikan nasional berfungsi mengembangkan kemampuan dan membentuk watak peradaban bangsa yang bermartabat dalam rangka mencerdaskan kehidupan bangsa, bertujuan untuk mengembangkan potensi peserta didik agar menjadi manusia yang beriman dan bertakwa kepada Tuhan Yang Maha Esa, berakhlak mulia, sehat, berilmu, cakap, kreatif, mandiri dan menjadi warga Negara yang demokratis serta bertanggung jawab.

Sekolah Menengah Kejuruan (SMK) bertujuan untuk mempersiapkan peserta didik menguasai keterampilan profesional untuk memasuki lapangan kerja dan sekaligus memberikan bekal untuk melanjutkan penddikan kejuruan yang lebih tinggi. 
SMK Negeri 1 Lubuk Pakam merupakan salah satu lembaga pendidikan formal yang memiliki Program Keahlian Teknik Gambar Bangunan yang mana lulusannya diharapkan memiliki kemampuan dan keterampilan sesuai kebutuhan dunia kerja khususnya berkaitan dengan bidang keahliannya. Pada Program Keahlian Teknik Gambar Bangunan ada tiga kelompok mata pelajaran yakni: Mata Pelajaran Normatif, Adaptif, dan Produktif. Dari ketiga kelompok mata pelajaran ini, kelompok mata pelajaran produktif merupakan salah satu mata pelajaran yang sangat penting, karena siswa dituntut untuk mempunyai pengetahuan, keterampilan, dan kemampuan yang merupakan bekal bagi para siswa untuk dapat menghadapi persaingan kerja. Salah satu mata pelajaran yang termasuk dalam mata pelajaran produktif tersebut adalah Mekanika Teknik. Mata pelajaran ini dianggap penting karena mekanika teknik dapat menghantarkan siswa kepada dasar memahami mata pelajaran produktif lainnya, seperti: mata pelajaran struktur beton, struktur baja, struktur kayu dan lain-lain.

Dalam hal ini, masih banyak siswa yang merasa mata pelajaran mekanika teknik adalah mata pelajaran yang sulit dan membingungkan, padahal yang menjadi hambatan selama ini dalam pembelajaran mekanika teknik adalah disebabkan kurang dikemasnya pembelajaran mekanika teknik dengan menggunakan model pembelajaran yang menarik, menantang dan menyenangkan. Para guru sering kali menyampaikan meteri secara lisan sehingga pembelajaran membosankan dan kurang menarik yang pada akhirnya hasil belajar siswa menjadi rendah.

Setelah dilakukan observasi pada tanggal 9 April 2016 diperoleh bahwa hasil belajar siswa belum semuanya mencapai Kriteria Ketuntasan Minimum (KKM) yang ditetapkan oleh pihak sekolah yaitu 70 , dan model pembelajaran yang ada di SMK Negeri 1 Lubuk Pakam masih mengarah pada pembelajaran langsung.

Untuk mencapai hasil belajar yang maksimal, saat ini berkembang berbagai model pembelajaran. Salah satu model pembelajaran yang kini banyak mendapat respon adalah model pembelajaran kontekstual. Melalui pembelajaran kontekstual diharapkan konsep-konsep materi pelajaran dapat diintegrasikan dalam konteks kehidupan nyata dengan harapan siswa dapat memahami apa yang dipelajarinya dengan lebih baik dan mudah. Sedangkan faktor internal yang dapat mempengaruhi belajar salah satunya adalah gaya belajar. Gaya belajar merupakan kecenderungan untuk mengadaptasi suatu strategi belajar tertentu dengan mencari dan mencoba secara aktif. Dengan memahami gaya belajar, strategi yang tepat dapat dipelajari dan keterampilan belajar juga dapat ditingkatkan. Gaya belajar merupakan kunci untuk mengembangkan kinerja dalam pekerjaan, dibidang akademik dan dalam situasi-situasi antar pribadi.

Berdasarkan pendahuluan di atas, maka tujuan dari penelitian ini adalah (1) Untuk mengetahui pengaruh penggunaan model pembelajaran Kontekstual dan model pembelajaran Konvensional terhadap hasil belajar Mekanika Teknik siswa kelas X Program Keahlian Teknik Gambar Bangunan SMK Negeri 1 Lubuk Pakam. (2) Untuk mengetahui pengaruh Gaya belajar kinestetik dan vgaya belajar visual siswa terhadap hasil belajar Mekanika Teknik siswa kelas X Program Keahlian Teknik Gambar Bangunan SMK Negeri 1 Lubuk Pakam. (3) Untuk mengetahui ada tidaknya interaksi antara model pembelajaran dengan gaya belajar terhadap hasil belajar Mekanika Teknik.

\section{KAJIAN PUSTAKA}

Belajar adalah usaha atau latihan agar anak didik diharapkan mengalami perubahan baik pengetahuan, perilaku maupun keterampilan. Belajar juga merupakan suatu rangkaian kegiatan jiwa raga untuk menuju ke perkembangan individu melalui rangkaian latihan secara terus menerus, yang berarti menyangkut unsur kognitif, afektif, dan psikomotorik dalam rangka untuk mencapai tujuan belajar. 
Hasil belajar adalah pencapaian yang didapatkan siswa dari proses pembelajaran yang diukur mengunakan tes, merupakan tolak ukur yang menentukan tingkat keberhasilan siswa dalam mengetahui suatu materi pelajaran. Hasil belajar merupakan indikator yang mengukur keberhasilan siswa dalam belajar.

Kontekstual adalah konsep belajar yang membantu guru mengkaitkan antara materi yang diajarkan dengan situasi dunia nyata siswa dan mendorong siswa membuat hubungan antara pengetahuan yang dimilikinya dengan penerapannya dalam kehidupan mereka sehari-hari, dengan melibatkan tujuh komponen utama pembelajaran kontekstual, yakni: kontruktivisme, bertanya, inkuiri, masyarakat belajar, pemodelan dan penilaian autentik. Tujuan utama kontekstual adalah membantu para siswa dengan cara yang tepat untuk mengaitkan makna pada pelajaranpelajaran akademik mereka.

Koncensional merupakan pembelajaran yang aktivitasnya di dominasi oleh pengajar yang kurang menuntut keaktifan siswa. Siswa adalah objek belajar yang terus menerus mendapatkan informasi dari suatu sumber yaitu guru.

Menurut De Porter dan Hemacki gaya belajar adalah kombinasi dari cara seseorang menyerap dan kemudian mengatur serta mengolah informasi. Gaya belajar merupakan kunci untuk mengembangkan kinerja dalam pekerjaan, di bidang akademik dan dalam situasi-situasi antar pribadi. Jika siswa hanya diajarkan dengan metode standar, sedikit saja yang dapat dipahami dari apa yang diberikan dalam proses pembelajaran. Gaya belajar dalam penelitian ini dibedakan menjadi dua, yaitu gaya belajar kinestetik dan gaya belajar visual.

Tipe kinestetik belajar dengan menggerakkan otot-otot tubuh mereka dan secara aktif terlibat dalam suatu kegiatan seperti roleplay, simulasi, eksperimen, usaha eksplorasi dan gerakan-gerakan tertentu atau berpartisipasi dalam sebuah aktifitas dalam kehidupan nyata mereka. Gaya belajar kinestetik mengharuskan individu yang bersangkutan menyentuh sesuatu yang memberikan informasi tertentu agar ia bisa mengingatnya.

Tipe visual yaitu belajar dengan cara melihat. Ada beberapa karakteristik yang khas bagai orang-orang yang menyukai gaya belajar visual ini. Pertama adalah kebutuhan melihat sesuatu (informasi/pelajaran) secara visual untuk mengetahuinya atau memahaminya, kedua memiliki kepekaan yang kuat terhadap warna, ketiga memiliki pemahaman yang cukup terhadap masalah artistik, keempat memiliki kesulitan dalam berdialog secara langsung, kelima terlalu reaktif terhadap suara, keenam sulit mengikuti anjuran secara lisan, ketujuh seringkali salah menginterpretasikan kata atau ucapan.

Relevansi adalah suatu sifat yang terdapat pada penelitian yang dapat membantu peneliti dalam memecahkan masalah. Penelitian ini dinilai relevan bila mempunyai topik yang sama, atau berhubungan dengan subjek yang diteliti.

Penelitian yang dilakukan oleh Daniel Solin Universitas Negeri Medan (Unimed) 2014 dengan judul "Pengaruh Strategi Pembelajaran Contextual Teaching And Learning (CTL) dan Ekspositori Berbasis Media Software EKTS Pada Hasil Belajar Siswa Mata Pelajaran MSPEM Pada Siawa Kelas XI SMK Negeri 5 Medan" menyimpulkan bahwa hasilbelajar Mengoperasikan Sistem Pengendali Elektromagnetik siswa yang diajarkan dengan strategi pembelajaran contextual teacing and learning (CTL) lebih tinggi dari hasil belajar siswa yang diajarkan dengan model pembelajaran ekspositori.

Penelitian yang dilakukan oleh Nurliza (2011) tentang "Pengaruh Strategi Pembelajaran dan Gaya Belajar Terhadap Hasil Belajar Siswa SD Negeri 101789 Deli Tua" hasli penelitian menunjukkan bahwa (1) hasil belajar IPA siswa yang diajarkan dengan strategi discovery lebih tinggi dibandingkan yang dibelajarkan dengan strategi ekspository (2) terdapat perbedaan hasil belajar IPA siswa yang memiliki gaya belajar visual dan kinestetik (3) terdapat 
interaksi antara strategi pembelajaran dan gaya belajar terhadap hasil belajar IPA.

\section{METODE PENELITIAN}

Penelitian ini dilaksanakan di SMK Negeri 1 Lubuk Pakam Program Keahlian Teknik Gambar Bangunan pada mata pelajaran Mekanika Teknik. Penelitian ini dilaksanakan pada kelas X semester ganjil (I) Tahun Pelajaran (T.P) 2016/2017. Populasi dalam penelitian ini adalah seluruh siswa kelas X bidang keahlian Teknik Gambar Bangunan SMK Negeri 1 Lubuk Pakam tahun pelajaran 2016/2017. Setelah populasi penelitian diketahui, maka langkah selanjutnya adalah pengambilan sampel penelitian. Pengambilan sampel penelitian secara acak. kelas X Program Keahlian Teknik Gambar Bangunan A berjumlah 35 orang sebagai siswa kelas eksperimen dan kelas X Program Keahlian Teknik Gambar Bangunan B berjumlah 35 orang siswa sebagai kelas kontrol.

Metode yang digunakan pada penelitian ini adalah penelitian eksperimen semu (Quasi Eksperimen). Dalam penelitian ini terdapat dua kelompok perlakuan yaitu satu kelompok sebagai kelas perlakuan model pembelajaran Kontekstual dan satu kelompok sebagai kelas perlakukan model pembelajaran Konvensional.

Variabel bebas dalam penelitian ini adalah : 1) Model Pembelajaran (Kontekstual) ; 2) Gaya Belajar. Sedangkan variabel terikat adalah hasil belajar Mekanika Teknik.

Defenisi operasional adalah defenisi yang diturunkan dari defenisi teoritis (konseptual) yang memuat indikatorindikator ubahan yang memungkinkan untuk dibuatkan butir instrumen. (1) Hasil belajar Mekanika Teknik adalah suatu hasil perubahan tingkah laku yang menyangkut perubahan kompetensi sikap, pengetahuan, dan keterampilan pada mata pelajaran mekanika Teknik. (2) Model Pembelajaran Kontekstual merupakan konsep belajar yang membantu guru mengaitkan antara materi pembelajaran dengan situasi dunia nyata peserta didik, dan mendorong peserta didik membuat hubungan antara pengetahuan yang dimiliknya dengan penerapannya dalam kehidupan sehari-hari. (3) Pembelajaran Konvensional adalah pembelajaran yang dilakukan dengan cara mentransfer ilmu pengetahuan kepada siswa sedangkan siswa lebih banyak sebagai penerima, pembelajaran konvensional dilakukan dengan ceramah yang diiringi dengan penjelasan, serta pembagian tugas dan latihan. (4) Gaya belajar kinestetik adalah cara siswa untuk memahami dan mengelola informasi melalui gerakan-gerakan fisik. Siswa kinestetik suka belajar melalui gerak dan paling baik menghafal informasi dengan mengasosiasikan gerakan dengan setiap fakta. (5) Gaya belajar visual adalah cara siswa untuk memahami dan mengelola informasu memalui pengamatan. Orang visual akan sangat mudah melihat atau membayangkan apa yang dibicarakan. Mereka sering melihat gambar yang berhubungan dengan kata atau perasaan dan mengerti suatu informasi bila melihat kejadian, melihat informasi tertulis atau bentuk gambar.

Kompetensi Dasar yang dipilih dalam penelitian ini adalah KD 3.4 yaitu "Menerapkan cara menyusun gaya dalam struktur bangunan".

Penilaian Hasil belajar kompetensi sikap dilakukan dengan menggunakan instrumen penilaian diri berupa lembar pengamatan penilaian sikap kerja sama dan tanggung jawab.

Penilaian hasil belajar kompetensi pengetahuan dilakukan dengan menggunakan tes pilihan berganda (multiple choice) yang terdiri empat pilihan. Jawaban yang benar diberi skor 1 dan jawaban yang salah diberi skor 0 .

Penilaian hasil belajar kompetensi keterampilan dilakukan dengan menggunakan tes tertulis essai sebanyak 5 soal dengan pemberian skor berdasarkan rubrik penilaian. Rubrik adalah daftar kriteria yang menunjukkan kinerja dan aspek-aspek atau konsep-konsep yang akan dinilai, dan gradasi mutu, mulai dari tingkat 
yang paling sempurna sampai yang paling rendah.

Instrumen gaya belajar dijaring dengan menggunakan angket yang terdiri dari 3 jawaban yang merentang dari "sering" sampai pada "jarang". Dimana setiap pilihan jawaban diberikan bobot nilai untuk pernyataan positif adalah sebagai berikut :sering $=2$, kadang-kadang $=1$, dan jarang $=$ 0 .

Uji coba instrumen penelitian ini dilakukan pada siswa kelas XI Program Keahlian Teknik Gambar Bangunan SMK Negeri 2 Medan Tahun Pelajaran 2016/2017 dengan jumlah 30 soal pilihan berganda. Instrumen yang baik harus memenuhi dua persyaratan penting yaitu valid dan reliabel. Untuk mengetahui apakah butir-butir soal yang disusun mempunyai indeks kesukaran, daya beda yang baik, maka diadakan uji coba instrumen.

\section{HASIL DAN PEMBAHASAN}

Rangkuman Penelitian Data Hasil Belajar Mekanika Teknik Model Pembelajaran Kontekstual dan Konvensional

\section{KOMPETENSI PENGETAHUAN}

\begin{tabular}{|c|c|c|}
\hline \multirow{2}{*}{ Statistik } & \multicolumn{2}{|c|}{ Kelas } \\
\cline { 2 - 3 } & Eksperimen & Kontrol \\
\hline Skor Tertinggi & 22 & 21 \\
\hline Skor Terendah & 13 & 9 \\
\hline Mean & 18.286 & 16.114 \\
\hline SD & 2.321 & 2.687 \\
\hline Varians & 5.387 & 7.222 \\
\hline $\mathbf{N}$ & $\mathbf{3 5}$ & $\mathbf{3 5}$ \\
\hline
\end{tabular}

\section{KOMPETENSI KETERAMPILAN}

\begin{tabular}{|c|c|c|}
\hline \multirow{2}{*}{ Statistik } & \multicolumn{2}{|c|}{ Kelas } \\
\cline { 2 - 3 } & Eksperimen & Kontrol \\
\hline Skor Tertinggi & 48 & 44 \\
\hline Skor Terendah & 10 & 10 \\
\hline Mean & 37.429 & 32.629 \\
\hline SD & 9.500 & 9.747 \\
\hline Varians & 90.252 & 95.005 \\
\hline $\mathbf{N}$ & $\mathbf{3 5}$ & $\mathbf{3 5}$ \\
\hline
\end{tabular}

KOMPETENSI SIKAP

\begin{tabular}{|c|c|c|}
\hline \multirow{2}{*}{ Statistik } & \multicolumn{2}{|c|}{ Kelas } \\
\cline { 2 - 3 } & Eksperimen & Kontrol \\
\hline Skor Tertinggi & 4 & 4.0 \\
\hline Skor Terendah & 3 & 2.0 \\
\hline Mean & 3.000 & 3.071 \\
\hline SD & 0.485 & 0.544 \\
\hline Varians & 0.235 & 0.296 \\
\hline $\mathbf{N}$ & $\mathbf{3 5}$ & $\mathbf{3 5}$ \\
\hline
\end{tabular}

Rangkuman Penelitian Data Hasil Belajar Mekanika Teknik Gaya Belajar Kinestetik dan Visual.

\section{KOMPETENSI PENGETAHUAN}

\begin{tabular}{|c|c|c|}
\hline \multirow{2}{*}{ Statistik } & \multicolumn{2}{|c|}{ Kelas } \\
\cline { 2 - 3 } & Visual & Kinestetik \\
\hline Skor Tertinggi & 21 & 22 \\
\hline Skor Terendah & 9 & 13 \\
\hline Mean & 16.558 & 18.222 \\
\hline SD & 2.746 & 2.391 \\
\hline Varians & 7.538 & 5.718 \\
\hline $\mathbf{N}$ & $\mathbf{4 3}$ & $\mathbf{2 7}$ \\
\hline
\end{tabular}

\section{KOMPETENSI KETERAMPILAN}

\begin{tabular}{|c|c|c|}
\hline \multirow{2}{*}{ Statistik } & \multicolumn{2}{|c|}{ Kelas } \\
\cline { 2 - 3 } & Visual & Kinestetik \\
\hline Skor Tertinggi & 48 & 48 \\
\hline Skor Terendah & 10 & 10 \\
\hline Mean & 33.209 & 38.000 \\
\hline SD & 10.448 & 8.283 \\
\hline Varians & 109.169 & 68.615 \\
\hline $\mathbf{N}$ & $\mathbf{4 3}$ & 27 \\
\hline
\end{tabular}


KOMPETENSI SIKAP

\begin{tabular}{|c|c|c|}
\hline \multirow{2}{*}{ Statistik } & \multicolumn{2}{|c|}{ Kelas } \\
\cline { 2 - 3 } & Visual & Kinestetik \\
\hline Skor Tertinggi & 4.0 & 4.0 \\
\hline Skor Terendah & 2.0 & 2.5 \\
\hline Mean & 2.9302 & 3.204 \\
\hline SD & 0.5298 & 0.444 \\
\hline Varians & 0.2807 & 0.197 \\
\hline $\mathbf{N}$ & 43 & 27 \\
\hline
\end{tabular}

Uji persyaratan analisis dilakukan untuk mengetahui apakah data penelitian sudah mempunyai sebaran normal serta untuk mengetahui apakah data penelitian homogen.

Uji normalitas terhadap data ubahan penelitian dilakukan dengan menggunakan rumus Lielifors.

Uji kenormalan data hasil belajar Mekanika Teknik siswa yang dibelajarkan dengan model pembelajaran Kontekstual (A1) dan Konvensional (A2).

Kompetensi Pengetahuan

\begin{tabular}{|c|c|c|c|c|}
\hline Kel & $\mathrm{N}$ & $\mathrm{L}_{0}$ & $\begin{array}{c}\mathrm{L}_{\text {Tabel }} \alpha \\
=0,05\end{array}$ & Simpulan \\
\hline A1 & 35 & 0,093 & 0,149 & Normal \\
A2 & 35 & 0,085 & 0,149 & Normal \\
\hline
\end{tabular}

Kompetensi Keterampilan

\begin{tabular}{|c|c|c|c|c|}
\hline Kel & $\mathrm{N}$ & $\mathrm{L}_{0}$ & $\begin{array}{c}\mathrm{L}_{\text {Tabel }} \alpha \\
=0,05\end{array}$ & Simpulan \\
\hline A1 & 35 & 0,073 & 0,149 & Normal \\
A2 & 35 & 0,117 & 0,149 & Normal \\
\hline
\end{tabular}

Kompetensi Sikap

\begin{tabular}{|c|c|c|c|c|}
\hline Kel & $\mathrm{N}$ & $\mathrm{L}_{0}$ & $\begin{array}{c}\mathrm{L}_{\text {Tabel }} \alpha \\
=0,05\end{array}$ & Simpulan \\
\hline A1 & 35 & 0,066 & 0,149 & Normal \\
A2 & 35 & 0,095 & 0,149 & Normal \\
\hline
\end{tabular}

Uji kenormalan data hasil belajar Mekanika Teknik siswa yang memiliki gaya belajar kinestetik (B1) dan gaya belajar visual (B2)
Kompetensi Pengetahuan

\begin{tabular}{|c|c|c|c|c|}
\hline Kel & $\mathrm{N}$ & $\mathrm{L}_{0}$ & $\begin{array}{c}\mathrm{L}_{\text {Tabel }} \alpha \\
=0,05\end{array}$ & Simpulan \\
\hline $\mathrm{B} 1$ & 27 & 0,086 & 0,165 & Normal \\
$\mathrm{B} 2$ & 43 & 0,058 & 0,135 & Normal \\
\hline
\end{tabular}

Kompetensi Keterampilan

\begin{tabular}{|c|c|c|c|c|}
\hline Kel & $\mathrm{N}$ & $\mathrm{L}_{0}$ & $\begin{array}{c}\mathrm{L}_{\text {Tabel }} \alpha \\
=0,05\end{array}$ & Simpulan \\
\hline $\mathrm{B} 1$ & 27 & 0,114 & 0,165 & Normal \\
$\mathrm{B} 2$ & 43 & 0,107 & 0,135 & Normal \\
\hline
\end{tabular}

Kompetensi Sikap

\begin{tabular}{|c|c|c|c|c|}
\hline Kel & $\mathrm{N}$ & $\mathrm{L}_{0}$ & $\begin{array}{c}\mathrm{L}_{\text {Tabel }} \alpha \\
=0,05\end{array}$ & Simpulan \\
\hline $\mathrm{B} 1$ & 27 & 0,104 & 0,166 & Normal \\
$\mathrm{B} 2$ & 43 & 0,133 & 0,135 & Normal \\
\hline
\end{tabular}

Uji kenormalan data hasil belajar Mekanika Teknik siswa diajar dengan pembelajaran Kontekstual dan Konvensional berdasarkan gaya belajar Kinestetik dan gaya belajar Visual.

Kompetensi Pengetahuan

\begin{tabular}{|c|c|c|c|c|}
\hline Kel & $\mathrm{N}$ & $\mathrm{L}_{0}$ & $\begin{array}{c}\mathrm{L}_{\text {Tabel }} \alpha \\
=0,05\end{array}$ & Simpulan \\
\hline A1B1 & 16 & 0,171 & 0,213 & Normal \\
A1B2 & 19 & 0,093 & 0,195 & Normal \\
A2B1 & 11 & 0,160 & 0,249 & Normal \\
A2B2 & 24 & 0,109 & 0,188 & Normal \\
\hline
\end{tabular}

Kompetensi Keterampilan

\begin{tabular}{|c|c|c|c|c|}
\hline Kel & $\mathrm{N}$ & $\mathrm{L}_{0}$ & $\begin{array}{c}\mathrm{L}_{\text {Tabel }} \alpha \\
=0,05\end{array}$ & Simpulan \\
\hline A1B1 & 16 & 0,096 & 0,213 & Normal \\
A1B2 & 19 & 0,112 & 0,195 & Normal \\
A2B1 & 11 & 0,151 & 0,249 & Normal \\
A2B2 & 24 & 0,133 & 0,188 & Normal \\
\hline
\end{tabular}

Kompetensi Sikap

\begin{tabular}{|c|c|c|c|c|}
\hline Kel & $\mathrm{N}$ & $\mathrm{L}_{0}$ & $\begin{array}{c}\mathrm{L}_{\text {Tabel }} \alpha \\
=0,05\end{array}$ & Simpulan \\
\hline A1B1 & 16 & 0,149 & 0,213 & Normal \\
A1B2 & 19 & 0,142 & 0,195 & Normal \\
A2B1 & 11 & 0,204 & 0,249 & Normal \\
A2B2 & 24 & 0,121 & 0,188 & Normal \\
\hline
\end{tabular}

Berdasarkan hasil uji normalitas data menunjukkan bahwa seluruh kelompok 
subjek berdistribusi normal, dengan demikian dapat disimpulkan bahwa sampel penelitian berasal dari populasi yang berdistribusi normal.

Untuk menguji homogenitas data digunakan uji $\mathrm{F}$ dan uji Barlette. Kriteria pengujian adalah jika $\mathrm{F}$ hitung lebih kecil dari $\mathrm{F}$ tabel pada signifikan $5 \%$ dan uji Barlett pada taraf signifikan $\left(\chi^{2}\right)=0,05$.

Uji homogenitas varians hasil belajar mekanika teknik siswa yang diajar dengan pembelajaran Kontekstual (A1) dan Konvensional (A2).

Kompetensi Pengetahuan

\begin{tabular}{|c|c|c|c|}
\hline Kel & $F_{\text {hitung }}$ & $\begin{array}{c}F_{\text {tabel }} \alpha \\
=0.05\end{array}$ & Simpulan \\
\hline $\begin{array}{r}\text { A1 } \\
\text { A2 }\end{array}$ & 1,34 & 1,75 & Homogen \\
\hline
\end{tabular}

Kompetensi Keterampilan

\begin{tabular}{|c|c|c|c|}
\hline Kel & $F_{\text {hitung }}$ & $\begin{array}{c}F_{\text {tabel }} \alpha \\
=0.05\end{array}$ & Simpulan \\
\hline $\begin{array}{r}\text { A1 } \\
\text { A2 }\end{array}$ & 1,06 & 1,75 & Homogen \\
\hline
\end{tabular}

Kompetensi Sikap

\begin{tabular}{|c|c|c|c|}
\hline Kel & $F_{\text {hitung }}$ & $\begin{array}{c}F_{\text {tabel }} \alpha \\
=0.05\end{array}$ & Simpulan \\
\hline $\begin{array}{r}\text { A1 } \\
\text { A2 }\end{array}$ & 1,26 & 1,746 & Homogen \\
\hline
\end{tabular}

Uji homogenitas varians hasil belajar mekanika teknik siswa yang memiliki gaya belajar Kinestetik (B1) dan Visual (B2)

Kompetensi Pengetahuan

\begin{tabular}{|c|c|c|c|}
\hline Kel & $F_{\text {hitung }}$ & $\begin{array}{c}F_{\text {tabel }} \alpha \\
=0.05\end{array}$ & Simpulan \\
\hline $\begin{array}{c}\text { B1 } \\
\text { B2 }\end{array}$ & 1,318 & 1,826 & Homogen \\
\hline \\
\begin{tabular}{|c|c|c|c|}
\hline Kompetensi Keterampilan \\
\hline $\begin{array}{c}\text { Kel } \\
\text { B1 } \\
\text { B2 }\end{array}$ & $F_{\text {hitung }}$ & $\begin{array}{c}F_{\text {tabel }} \alpha \\
=0.05\end{array}$ & Simpulan \\
\hline \begin{tabular}{c} 
Kompetensi Sikap \\
\hline Kel
\end{tabular} & $F_{\text {hitung }}$ & $\begin{array}{l}F_{\text {tabel }} \alpha \\
=0.05\end{array}$ & Simpulan \\
\hline $\begin{array}{c}\text { B1 } \\
\text { B2 }\end{array}$ & 1,423 & 1,826 & Homogen \\
\hline
\end{tabular}
\end{tabular}

Uji Homogenitas Varians Pada Empat Kelompok Sel Rancangan Eksperimen.

Kompetensi Pengetahuan

\begin{tabular}{|c|c|c|c|}
\hline Kel & $\chi_{\mathrm{h}}^{2}$ & $\chi_{\mathrm{t}(0,05)}^{2}$ & Simpulan \\
\hline A1B1 & & & \\
A1B2 & 5,705 & 7,815 & Homogen \\
A2B1 & & & \\
A2B2 & & & \\
\hline
\end{tabular}

Kompetensi Keterampilan

\begin{tabular}{|c|c|c|c|}
\hline Kel & $\chi_{\mathrm{h}}^{2}$ & $\chi_{\mathrm{t}(0,05)}^{2}$ & Keterangan \\
\hline A1B1 & & & \\
A1B2 & 4,764 & 7,815 & Homogen \\
A2B1 & & & \\
A2B2 & & & \\
\hline
\end{tabular}

Kompetensi Sikap

\begin{tabular}{|c|c|c|c|}
\hline Kel & $\chi_{\mathrm{h}}^{2}$ & $\chi_{\mathrm{t}(0,05)}^{2}$ & Keterangan \\
\hline A1B1 & & & \\
A1B2 & 3,462 & 7,815 & Homogen \\
A2B1 & & & \\
A2B2 & & & \\
\hline
\end{tabular}

Berdasarkan hasil uji homogenitas data menunjukkan bahwa seluruh kelompok subjek penelitian berasal dari populasi yang bersifat homogen.

Persyaratan pengujian analisis untuk analiysis of varians untuk data tiap kelompok telah dipenuhi, yaitu deta setiap kelompok berdistribusi normal, memiliki varians yang homogen dan dari sampel yang ditentukan secara random. Dengan demikian uji hipotesis dengan analiysis of varians dua jalur dari hasil belajar mekanika teknik dapat dilakukan. Berikut ini akan disajikan pengujian hipotesis penelitian.

Kompetensi Pengetahuan

\begin{tabular}{|l|c|c|c|}
\hline Sumber Variansi & JK & Fh & $\begin{array}{c}\text { Ft }(\alpha= \\
0,05)\end{array}$ \\
\hline $\begin{array}{l}\text { Strategi } \\
\text { pembelajaran (A) }\end{array}$ & 45.93 & $\mathbf{7 . 8 1 8}$ & 3.982 \\
\hline Gaya Belajar (B) & 72.66 & $\mathbf{1 2 . 3 6 8}$ & 3.982 \\
\hline Interaksi (AB) & 4.89 & 0.832 & $\mathbf{3 . 9 8 2}$ \\
\hline Gallat & 387.73 & - & - \\
\hline \multicolumn{1}{|c|}{ Total } & 511.20 & - & - \\
\hline
\end{tabular}


Kompetensi Keterampilan

\begin{tabular}{|l|c|c|c|}
\hline Sumber Variansi & JK & Fh & $\begin{array}{c}\mathrm{Ft}(\alpha= \\
0,05)\end{array}$ \\
\hline $\begin{array}{l}\text { Strategi } \\
\text { pembelajaran (A) }\end{array}$ & 380.66 & $\mathbf{4 . 2 1 8}$ & 3.982 \\
\hline Gaya Belajar (B) & 263.03 & 2.914 & $\mathbf{3 . 9 8 2}$ \\
\hline Interaksi (AB) & 149.47 & 1.656 & $\mathbf{3 . 9 8 2}$ \\
\hline Gallat & 5956.62 & - & - \\
\hline \multicolumn{1}{|c|}{ Total } & 6749.77 & - & - \\
\hline
\end{tabular}

Kompetensi Sikap

\begin{tabular}{|c|c|c|c|}
\hline Sumber Variansi & JK & Fh & $\begin{array}{c}\mathrm{Ft}(\alpha= \\
0,05)\end{array}$ \\
\hline $\begin{array}{l}\text { Strategi } \\
\text { pembelajaran (A) }\end{array}$ & 1.24 & 5.203 & 3.982 \\
\hline Gaya Belajar (B) & 0.09 & 0.375 & 3.982 \\
\hline Interaksi (AB) & 1.10 & 4.602 & 3.982 \\
\hline Gallat & 15.73 & - & - \\
\hline Total & 18.16 & - & - \\
\hline
\end{tabular}

menggunakan uji ANAVA, Hipotesis yang diuji berbentuk :

1. Siswa yang diajar dengan strategi pembelajaran kontekstual memperoleh hasil belajar mekanika teknik lebih tinggi dibandingkan dengan siswa yang diajar denga strategi pembelajaran konvensional.

Hipotesis statistik yang diuji adalah :

$$
\begin{aligned}
& \mathrm{H}_{\mathrm{o}}: \mu \mathrm{A}_{1} \leq \mu \mathrm{A}_{2} \\
& \mathrm{H}_{\mathrm{a}}: \mu \mathrm{A}_{1}>\mu \mathrm{A}_{2}
\end{aligned}
$$

Dari hasil perhitungan uji hipotesis dengan rumus uji ANAVA data kompetensi pengetahuan diperoleh bahwa $\mathrm{F}_{\text {hitung }}$ lebih besar dari $\mathrm{F}_{\text {tabel }}(7,818>$ 3.982), data kompetensi keterampilan diperoleh bahwa $F_{\text {hitung }}$ lebih besar dari $F_{\text {tabel }}(4,218>3,982)$, data kompetensi sikap diperoleh bahwa $F_{\text {hitung }}$ lebih besar dari $F_{\text {tabel }}(5,293>3,982)$. Maka $H_{0}: \mu A_{1} \leq \mu A_{2}$ ditolak dan $H_{a}: \mu A_{1}>\mu A_{2}$ diterima, dengan demikian hasil belajar mekanika teknik siswa kompetensi pengetahuan, keterampilan dan sikap yang dibelajarkan dengan menggunakan model Pembelajaran Kontekstual lebih tinggi dibandingkan hasil belajar siswa yang dibelajarkan dengan menggunakan model pembelajaran Konvensional.
2. Siswa yang memiliki gaya belajar kinestetik memperoleh hasil belajar mekanika teknik lebih tinggi dibandingkan dengan siswa yang memiliki gaya belajar visual.

Hipotesis statistic yang diuji adalah :

$$
\begin{aligned}
& \mathrm{H}_{\mathrm{o}}: \mu \mathrm{B}_{1} \leq \mu \mathrm{B}_{2} \\
& \mathrm{H}_{\mathrm{a}}: \mu \mathrm{B}_{1}>\mu \mathrm{B}_{2}
\end{aligned}
$$

Dari hasil perhitungan uji hipotesis dengan rumus uji ANAVA data kompetensi pengetahuan diperoleh bahwa $F_{\text {hitung }}$ lebih besar dari $F_{\text {tabel }}(12,368>$ 3,982), data kompetensi keterampilan diperoleh bahwa $F_{\text {hitung }}$ lebih kecil dari $F_{\text {tabel }}(2,914<3,982)$. data kompetensi sikap diperoleh bahwa $F_{\text {hitung }}$ lebih kecil dari $F_{\text {tabel }}(0,375<3,982)$. Maka untuk kompetensi pengetahuan $H_{0}: \mu A_{1} \leq \mu A_{2}$ ditolak dan $H_{a}: \mu A_{1}>\mu A_{2}$ diterima, dan untuk kompetensi keterampilan dan sikap $H_{0}: \mu A_{1} \leq \mu A_{2} \quad$ diterima dan $H_{a}: \mu A_{1}>\mu A_{2}$ ditolak, dengan demikian hasil belajar mekanika teknik siswa kompetensi pengetahuan yang dibelajarkan memiliki gaya belajar kinestetik lebih tinggi dibandingkan hasil belajar siswa yang memiliki gaya belajar visual.

3. Tetdapat interaksi antara model pembelajaran dan gaya belajar terhadap hasil belajar mekanika teknik.

Hipotesis statistic yang diuji adalah :

$$
\begin{aligned}
& \mathrm{H}_{\mathrm{o}}: \mathrm{A} \times \mathrm{B}=0 \\
& \mathrm{H}_{\mathrm{a}}: \mathrm{A} \times \mathrm{B} \neq 0
\end{aligned}
$$

Dari hasil perhitungan uji hipotesis dengan rumus uji ANAVA data kompetensi pengetahuan diperoleh bahwa $F_{\text {hitung lebih kecil dari } F_{\text {tabel }}(0,832<}^{<}$ 3,982), data kompetensi keterampilan diperoleh bahwa $F_{\text {hitung }}$ lebih kecil dari $F_{\text {tabel }}(1,656<3,982)$, data kompetensi sikap diperoleh bahwa $F_{\text {hitung }}$ lebih besar dari $F_{\text {tabel }}(4,602>3,982)$. Maka untuk kompetensi pengetahuan dan keterampilan $\mathrm{H}_{\mathrm{o}}$ : A x B $=0$ diterima dan $\mathrm{H}_{\mathrm{a}}: \mathrm{A} \times \mathrm{B} \neq 0$ ditolak, dan untuk kompetensi sikap $\mathrm{H}_{\mathrm{o}}$ : A x $\mathrm{B}=0$ ditolak dan $\mathrm{H}_{\mathrm{a}}: \mathrm{A} \times \mathrm{B} \neq 0$ diterima, dengan demikian terdapat interaksi antara model 
pembelajaran dan gaya belajar terhadap hasil belajar mekanika teknik pada kompetensi sikap.

Untuk mengetahui interaksi antara strategi pembelajaran dan gaya belajar dalam mempengaruhi hasil belajar mekanika teknik kompetensi sikap dilakukan uji lanjut dengan menggunakan uji Scheffe. Berikut ringkasan uji Scheffe mekanika teknik kompetensi sikap.

\begin{tabular}{|c|l|c|c|c|}
\hline No & \multicolumn{1}{|c|}{$\begin{array}{c}\text { Kelompok } \\
\text { Data }\end{array}$} & $F_{\text {hitung }}$ & $\mathrm{F}_{\text {tabel }}$ & Kesimpulan \\
\hline 1 & $\begin{array}{l}\text { Kelompok } \\
\text { A1B1 : A2B1 }\end{array}$ & 0,991 & 2,742 & $\begin{array}{c}\text { Tidak } \\
\text { Signifikan }\end{array}$ \\
\hline 2 & $\begin{array}{l}\text { Kelompok } \\
\text { A1B1 : A1B2 }\end{array}$ & 9,781 & 2,742 & Signifikan \\
\hline 3 & $\begin{array}{l}\text { Kelompok } \\
\text { A1B1 : A2B2 }\end{array}$ & 1,927 & 2,742 & $\begin{array}{c}\text { Tidak } \\
\text { Signifikan }\end{array}$ \\
\hline 4 & $\begin{array}{l}\text { Kelompok } \\
\text { A2B1 : A1B2 }\end{array}$ & 3,139 & 2,742 & Signifikan \\
\hline 5 & $\begin{array}{l}\text { Kelompok } \\
\text { A2B1 : A2B2 }\end{array}$ & 0,025 & 2,742 & $\begin{array}{c}\text { Tidak } \\
\text { Signifikan }\end{array}$ \\
\hline 6 & $\begin{array}{l}\text { Kelompok } \\
\text { A2B2 : A1B2 }\end{array}$ & 3,986 & 2,742 & Signifikanm \\
tek
\end{tabular}

\section{KESIMPULAN}

Berdasarkan hasil penelitian yang telah diuraikan, maka dapat ditarik kesimpulan sebagai berikut :

1. Hasil belajar mekanika teknik siswa yang dibelajarkan dengan model pembelajaran kontekstual menunjukkan pengaruh yang signifikan pada hasil belajar kompetensi pengetahuan, keterampilan dan sikap. Hal ini terlihat pada uji hipotesis kompetensi pengetahuan diperoleh $\mathrm{F}_{\text {hitung }}=7,818$ lebih besar dari $\mathrm{F}_{\text {tabel }}=3,982$, pada uji hipotesis keterampilan $\mathrm{F}_{\text {hitung }}=4,217$ lebih besar dari $\mathrm{F}_{\text {tabel }}=3,982$, pada uji hipotesis sikap $\mathrm{F}_{\text {hitung }}=5,203$ lebih besar dari $F_{\text {tabel }}=3,982$. Maka dapat disimpulkan bahwa penggunaan model pembelajaran kontekstual memberi pengaruh yang signifikan terhadap hasil hasil belajar mekanika teknik siswa kelas X Program Keahlian Teknik Gambar Bangunan SMK Negeri 1 Lubuk Pakam.
2. Hasil belajar siswa yang memiliki gaya belajar kinestetik menunjukkan pengaruh yang signifikan terhadap hasil belajar mekanika teknik kompetensi pengetahuan, tetapi tidak memberikan pengaruh yang signifikan terhadap hasil belajar mekanika teknik kompetensi keterampilan dan sikap. Hal ini terlihat pada uji hipotesis kompetensi pengetahuan diperoleh $\mathrm{F}_{\text {hitung }}=12,368$ lebih besar dari $F_{\text {tabel }}=3,982$, pada uji hipotesis keterampilan $F_{\text {hitung }}=2,914$ lebih kecil dari $F_{\text {tabel }}=3,982$, pada uji hipotesis sikap $F_{\text {hitung }}=0,275$ lebih kecil dari $F_{\text {tabel }}=3,982$. Maka dapat disimpulkan bahwa gaya belajar kinestetik memberi pengaruh yang signifikan terhadap hasil hasil belajar mekanika teknik siswa kompetensi pengetahuan kelas X Program Keahlian Teknik Gambar Bangunan SMK Negeri 1 Lubuk Pakam.

Terdapat interaksi antara model embelajaran dengan gaya belajar dalam tekniksiswa kompetensi sikap yaitu $F_{1}$ lebih besar dari $\mathrm{F}_{\text {tabel }}(4,602>3,982)$, namun tidak terdapat interaksi antara model pembelajaran dengan gaya belajar dalam mempengaruhi hasil belajar mekanika teknik kompetensi pengetahuan yaitu $\mathrm{F}_{\text {hitung }}$ lebih kecil dari $F_{\text {tabel }}(0,832<3,982)$ dan kompetensi keterampilan yaitu $\mathrm{F}_{\text {hitung }}$ lebih kecil dari $\mathrm{F}_{\text {tabel }}(1,656<3,982)$. Maka dapat disimpulkan bahwa terdapat interaksi antara model pembelajaran dan gaya belajar terhadap hasil belajar mekanika teknik kompetensi sikap siswa kelas X Program Keahlian Teknik Gambar Bangunan SMK Negeri 1 Lubuk Pakam.

\section{DAFTAR PUSTAKA}

Abdurrahman, Mulyono. (1999). Pendidikan bagi anak berkesulitan belajar. Jakarta: Rineka Cipta.

Anisa (2009). Kelebihan Pembelajaran CTL. [Online]. Tersedia http://www.Sekolahdasar.net/2012/05 /kelebihan-dan-kelemahan- 
pembelajaran.html [diakses 12 mei 2016].

Arikunto, Suharsimi. 2003. Prosedur Penelitian Suatu Pendekatan Praktek. Jakarta : Rineka Cipta.

De Porter, Bobbi. dan Mike Hernachi. 2008. Quantum Learning: Membiasakan Belajar Nyaman dan Menyenangkan. Bandung: Kaifa.

Dimiyati dan Mudjono. (2006). Belajar dan Pembelajaran.Jakarta: Rineka Cipta.

Djaramah. 1996. Strategi belajar mengajar. Jakarta: Rineka Cipta.

Dzaki. (2009). Kelemahan Pembelajaran CTL. [Onlen]. Tersedia : http://www.sekolahdasar. net/2012/05/kele bihan-dankelemahan-pembelajaran.html [diakses 12 mei 2016]

Jendela Informasi. (2015). Model Pembelajaran Konvensional. [Onlen]. Tersedia http://jendelainformasi15.blogspot.co. id/2015/10/model-pembelajarankonvensional.html [diakses 12 mei 2016]

Muslich, M. (2007). KTSP pembelajaran berbasis kompetensi dan kontekstual. Jakarta: Bumi Aksara.

Ngalimun. (2012). Strategi dan Model Pembelajaran. Yogyakarta : Aswaja Pressindo.

Nurliza. (2011). Pengaruh Strategi Pembelajaran dan Gaya Belajar Terhadap Hasil Belajar Siswa SD Negeri 101798 Delitua. Tesis. Program Pasca Sarjana Universitas Negeri Medan.

Sahnur, Elvy. N (2010). Pengaruh Strategi Pembebelajaran dan Gaya Belajar Terhadap Hasil Belajar Mengikuti Prosedur Kesehatan dan Keselamatan Kerja Di SMK Ar-Rahman Medan. Tesis. Program Pasca Sarjana Universitas Negeri Medan
Sani, Ridwan Abdullah. (2013). Inovasi Pembelajaran. Jakarta: Bumi Aksara.

Sanjaya, W. (2006). Strategi Pembelajaran Berorientasi Standar Proses Pendidikan. Jakarta: Kencana Prenada Media Group.

Sanjaya, W. (2013). Strategi Pembelajaran Berorientasi Standar Proses Pendidikan. Jakarta: Kencana Pranada Media Group.

Sardiman, A.M. (2006). Interaksi dan Motifasi Belajar Mengajar. Jakarta: Raja Grafindo Persada.

Solin, Daniel. (2014). Pengaruh Strategi Pembelajaran Contextual Teaching And Learning (CTL) dan Ekspositori Berbasis Media Software EKTS Pada Hasi Belajar Siswa Mata Pelajaran MSPEM Pada Siswa Kelas XI TITL SMK Negeri 5 Medan. Skripsi. Program Pendidikan Teknik Elektro Fakultas Teknik Universitas Negeri Medan.

Sudjana, Nana. (2009). Penilaian Hasil Proses Belajar Mengajar. Bandung: Remaja Rosdakarya.

Sugiyono (2009). Metode Penelitian Kuantitatif, Kualitatif dan Rnd. Bandung: Alfabeta

Sutikno, Sobry. (2013). Belajar dan Pembelajaran. Lombok: Holistica.

Syamsudin, M.R. (2012). Statika Bangunan. [Online]. Tersedia: (http://materiesem ka.blogspot.com/2012/01/kompetensi .html/) [diakses 10 Juni 2014].

Trianto. (2009). Mendesain Model Pembelajaran Inovatif Produktif. Jakarta: Perpustakaan Nasional.

Trianto. (2010). Model Pembelajaran Terpadu. Jakarta : Bumi Aksara

Uno, B. Hamzah. (2011). Perencanaan Pembelajaran. Jakarta: Bumi Aksara. 
Jurnal Pendidikan Teknologi dan Kejuruan: Vol. 19 No. 2 November 2017 